\title{
Renal disease, epidermal necrosis, and epithelial cell antibodies
}

\author{
J E Deal, R W Groves, A W Harmer, K I Welsh, D M MacDonald, S P A Rigden
}

\begin{abstract}
Objective-To describe the association between epithelial cell IgM, which has previously been associated with an increased incidence of loss of renal graft in children, with a novel cutaneous eruption and unexplained native renal disease.

Design-Observational study on children with epithelial cell antibody presenting with unexplained renal or skin disease.

Setting-General paediatric department and regional paediatric nephrology unit.

Patients-Six children (five girls, one boy), who presented to the unit in 1989-90.

Results-Three children, two of whom had a history of a hyperpigmented rash, presented with hypertension, proteinuria, and impaired renal function. Renal biopsy specimens from two of these children showed severe arteriolar endothelial cell swelling with arteriolar occlusion. These children fully recovered after treatment with antihypertensive drugs. The third child developed end stage renal failure and required dialysis. Three other children presented with an unusual cutaneous eruption but no evidence of renal disease. Histology of the skin lesions showed acute epidermal necrosis and features consistent with a viral infection.

Conclusions - The aetiology and pathogenesis of the epithelial cell antibody are unknown. These cases indicate that it may have a role in native kidney disease and focal epidermal necrosis. Clinical and histological features suggest that the antibody may be associated with a viral infection.
\end{abstract}

\section{Introduction}

An IgM antibody directed against an epithelial cell line, A549, has been detected by flow cytometry ${ }^{1}$ in children undergoing renal transplantation, and its presence strongly correlates with an increased incidence of graft loss. ${ }^{2}$ In most children with this antibody graft loss was early and histological changes were found that were consistent with antibody mediated rejection: interstitial haemorrhage and swelling and vacuolation of arteriolar and capillary endothelial cells. We do not know whether the association between the presence of the antibody in renal graft recipients and graft loss is causal or coincidental. The aetiology and pathogenicity of the antibody are unknown, but preliminary findings show that in normal renal tissue it binds to distal tubular epithelial cells and vascular endothelium (B Hartley, personal communication).

The antibody has also been detected in people who have not received transplants, including healthy

Clinical details of six children

\begin{tabular}{|c|c|c|c|c|c|c|}
\hline $\begin{array}{l}\text { Case } \\
\text { No }\end{array}$ & $\begin{array}{c}\text { Age } \\
\text { (years) }\end{array}$ & Sex & Rash & Proteinuria & Hypertension & Renal function \\
\hline $\begin{array}{l}1 \\
2 \\
3 \\
4 \\
5\end{array}$ & $\begin{array}{l}7 \cdot 5 \\
9 \\
7 \\
10 \cdot 3 \\
12 \cdot 3 \\
15 \cdot 8\end{array}$ & $\begin{array}{l}\mathbf{F} \\
\mathbf{F} \\
\mathbf{F} \\
\mathbf{F} \\
\mathbf{F} \\
\mathbf{M}\end{array}$ & $\begin{array}{c}+ \\
+ \\
++ \\
++ \\
++\end{array}$ & $\begin{array}{l}++ \\
++\end{array}$ & $\begin{array}{c}+++ \\
++ \\
\\
++\end{array}$ & $\begin{array}{l}\text { Acute renal failure } \\
\text { Chronic renal failure } \\
\text { Normal } \\
\text { Normal } \\
\text { Normal } \\
\text { Acute renal failure }\end{array}$ \\
\hline
\end{tabular}

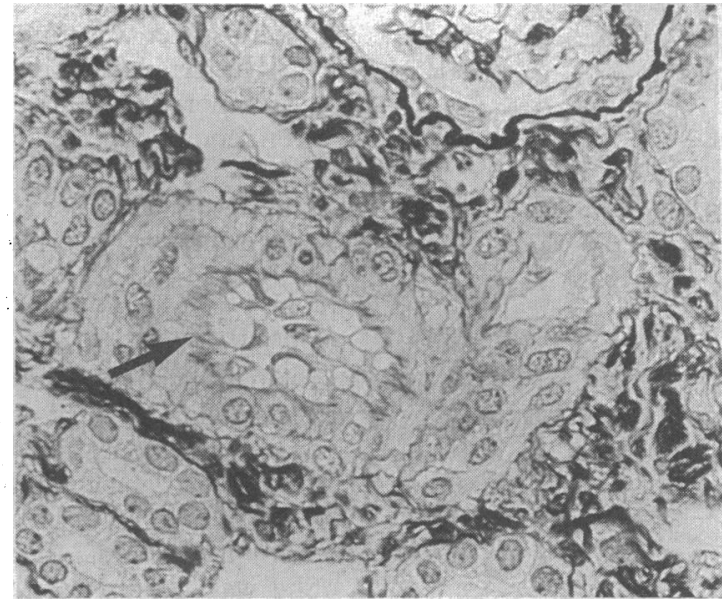

FIG 1-Renal biopsy specimen showing vascular endothelial cell swelling and vacuolation (arrows). Silver methanamine stain counterstained with haematoxylin and eosin. (Magnification $\times 400)$

members of staff and parents of children undergoing transplantation. In these subjects it does not seem to be associated with any specific clinical signs or symptoms. However, we also detected the antibody in six children who had not received transplants but who presented to our unit in 1989-90 with systemic disease. We describe the clinical features of these children and speculate on their association with the antibody.

\section{Case histories}

The table shows the clinical details of the six patients (five Afro-Caribbean girls, one white boy). All the children had a prodromal flu-like illness with fever, non-specific aches and pains, lethargy, and headaches. There was no history of contact with recognised infectious diseases. The children in cases 4 and 5 were sisters, and their mother also had the antibody detected in her serum, though she had no symptoms. The parents and three siblings of the child in case 6 had also had symptoms of a viral-like illness and all were positive for the antibody, although no other member of the family had cutaneous or renal disease.

\section{CASE 1}

This child presented with accelerated hypertension, proteinuria, and acute renal failure. She had had a hyperpigmented rash on her arms and legs three to four months before presentation, which had consisted of numerous $0 \cdot 5-2 \cdot 0 \mathrm{~cm}$ circular lesions. The lesions had faded leaving hyperpigmented macules. Renal ultrasonography showed normal size kidneys with increased echogehicity, and computed tomography showed bilateral areas of low attenuation in structurally normal kidneys, which suggested ischaemia. Renography with technetium-99m labelled dimercaptosuccinic acid (DMSA) showed bilateral patchy uptake; intravenous úrography and micturating cystourethrography gave normal results; and renal arteriography showed normal main vessels but small irregular renal arteries with distal pruning. Segmental occlusion of glomerular tufts by eosinophilic material, mild patchy interstitial oedema, and swelling and vacuo-
Paediatric Nephrology,

Guy's Hospital, London SE1 9RT.

BMF 1991;303:161-3 
lation of vascular endothelial cells were found on renal biopsy (fig 1). There was no deposition of complement or immunoglobulins.

She had neutrophil leucocytosis and thrombocytosis. She was weakly positive for nuclear and parietal cell antibodies and positive for neutrophil cytosolic IgM. Her complement levels were normal except for a raised $\mathrm{C} 3$ titre. Her titres for antistreptolysin $\mathrm{O}$ and antiDNAse $B$ were raised, suggesting recent streptococcal infection.

She was treated with antihypertensive drugs and six months later was normotensive without any treatment. Her renal function and renal biopsy specimen appeared normal and less uptake of ${ }^{99} \mathrm{~T}$ Tc-DMSA was seen on renography.

CASE 2

This girl had a hyperpigmented rash similar to that described in case 1 three to four months before presenting with hypertension, proteinuria, and chronic renal failure. The rash had faded leaving hyperpigmented macules. There was no evidence of vesicoureteric reflux or renal scarring and she had normal sized kidneys. Renal biopsy showed severe irreversible chronic renal damage of unknown cause with normal blood vessels. Immunoperoxidase studies showed deposition of $\operatorname{IgM}, \mathrm{C} 3$, and Clq.

She was weakly positive for nuclear and smooth muscle antibodies, but her complement concentrations were normal. She was treated with antihypertensive drugs and her renal function was managed medically, but her condition deteriorated and she became dependent on dialysis.

\section{CASES 3-5}

All these children presented with a short history of a few hyperpigmented lesions (up to three) that were predominantly distally sited on the arms and legs. The lesions were oval or round, $2-3 \mathrm{~cm}$ in diameter, tender, hyperpigmented, and had an erythematous base with incipient bullous change suggestive of epidermal necrosis (fig 2). One week after development the necrotic epidermis, which became dry, sloughed off leaving a hypopigmented macule. These areas subsequently repigmented, producing a peripheral hyperpigmented halo. None of the girls had evidence of renal disease at presentation.

Skin biopsy specimens from two of the girls (cases 3 and 4) showed acute epidermal necrosis with a moderate perivascular infiltrate comprising lymphocytes, macrophages, and eosinophils. Multinucleate keratinocytes were seen at the edge of the lesions, and some epidermal cells contained nuclear inclusion bodies (fig 3). Haematological investigations gave normal results. The girl in case 4 was weakly positive

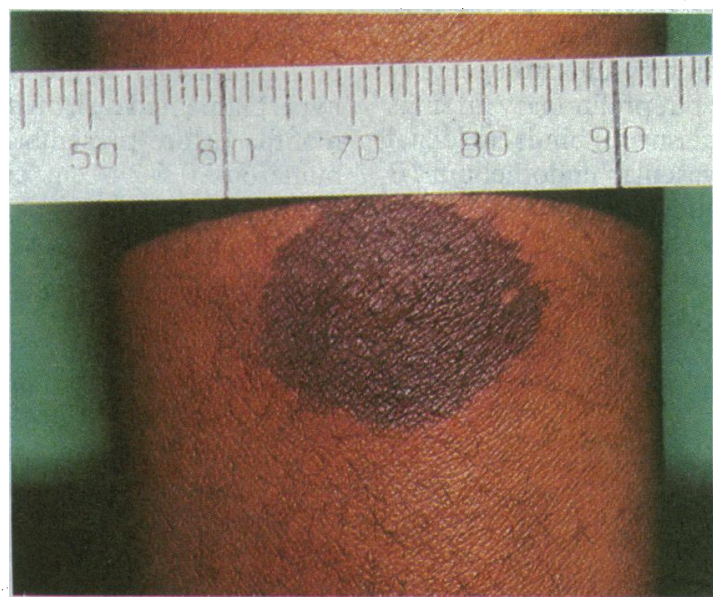

FIG 2-Typical lesion from case 4 showing hyperpigmented centre and inflammatory rim

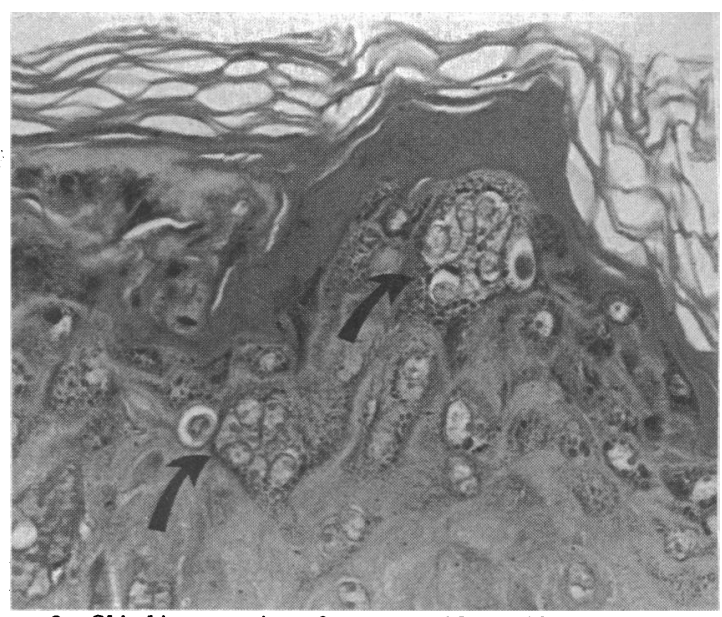

FIG 3-Skin biopsy specimen from case 2. Note epidermal giant cells and multiple intranuclear inclusion bodies (arrows). Haematoxylin and eosin stain. (Magnification $\times 125$ )

for smooth muscle antibodies and for neutrophil cytosolic IgM and IgG. Her sister (case 5) also was weakly positive for neutrophil cytosolic IgM. None of these children received any treatment.

\section{CASE 6}

This boy presented with accelerated hypertension, proteinuria, and acute renal failure. He had no history of hyperpigmented rash. Renal ultrasonography showed normal sized kidneys and increased echogenicity. Scanning with Tc-DMSA gave abnormal results, but the results of arteriography were normal. The appearance of his renal biopsy specimen was similar to that in case 1 with segmental occlusion of glomerular tufts, patchy interstitial oedema, and swelling and vacuolation of vascular endothelial cells. There was no deposition of complement or immunoglobulins. Haematological investigations showed a slightly raised erythrocyte sedimentation rate $(31 \mathrm{~mm}$ in first hour). The results of screening for autoantibodies and neutrophil cytosolic immunoglobulin were negative. He was treated with antihypertensive drugs and three months later he had stopped all treatment and had normal renal function and normal results on scanning with ${ }^{9{ }^{m}} \mathrm{Tc}$-DMSA.

All six children had epithelial cell IgM antibody at follow up 9-12 months after presentation.

\section{Discussion}

These children are clinically heterogeneous but have in common the presence of an epithelial cell antibody in their serum. Investigations did not find any of the previously recognised causes of glomerulonephritis, vasculitis, systemic disease, renal failure, or epidermal necrosis. In patients with renal transplants the presence of epithelial cell antibody is associated with antibody mediated vascular rejection. The appearances of biopsy specimens in two of the three children with native renal disease were similar and have not been described before in native kidneys, suggesting that the renal disease may have been linked to the presence of this antibody.

The skin lesions in cases 3-5 were unusual both clinically and histologically. All these girls were of Afro-Caribbean descent. None of the children who have received transplants, including those of AfroCaribbean descent, and in whom the epithelial cell antibody has been detected have had a history of rashes. Histological examination showed keratinocyte. giant cell formation and intranuclear inclusions, which are typical of virus infection. There was no ballooning degeneration or other signs typical of herpes infection. Some features of the histology in these children 
resembled those seen in skin biopsy specimens and oral mucous membrane lesions (Koplick spots) from children with measles. ${ }^{3}$

An alternative explanation of the skin lesions would be erythema multiforme or a fixed drug eruption. Although some of the histopathological results might be compatible with these diagnoses, ${ }^{45}$ the presence of multinucleate keratinocytes and inclusion bodies would be unusual. No history was obtained, on close questioning, of taking any drug, including proprietary and traditional remedies.

Although the cause of the signs and symptoms seen in these children is unknown there were various clinical aspects that suggest a viral aetiology and, by extrapolation, a viral association with epithelial cell antibody. All our patients had symptoms suggestive of a preceding viral illness; evidence of streptococcal infection was found in only one. None of the children had parvovirus antibodies. Two of the patients lived together, and their mother and the parents and siblings of the boy in case 6 all tested positive for the antibody, which is compatible with an infectious aetiology. The patients all came from south east London but apart from the two sisters had not been in contact with each other.

Systemic and renal disease associated with circulating antibodies and immune complexes is well recognised in systemic lupus erythematosus, Goodpasture's syndrome, Wegener's granulomatosis, and small vessel polyarteritis. ${ }^{6}$ The presence of antibodies in these disorders does not necessarily, however, correlate with the severity and spectrum of disease. In Goodpasture's syndrome the antibody is known to be pathogenic but in other disorders the role of circulating antibodies and immune complexes is less clear. Antibodies have also been implicated in certain skin disorders. Antibodies to intercellular components of the stratum spinosum have been found in $90 \%$ of cases of pemphigus vulgaris, and in $70 \%$ of cases of bullous pemphigoid antibodies to basement membrane zone antigens of the stratified epithelium have been found.?

JD was supported by Action Research for the Crippled Child.

1 Harmer AW, Haskard D, Koffman CG, Welsh KI. Novel antibodies associated with unexplained loss of renal allografts. Transpl Int 1990;3:66-9.

2 Harmer AW, Rigsden SPA, Koffman CG, Welsh KI. Preliminary report: dramatic rise in renal allograft failure rate. Lancet 1990;335:1184-5.

Ackerman AB, Suringa DWR. Multinucleate epidermal cells in measles. Arch Dermatol 1971;103:180-4.

4 Bedi TR, Pinkus H. Histopathological spectrum of erythema multiforme.

Brf Dermatol 1976;95:243-50.
5 Lever WF, Schaumberg-Lever G, eds. Histopathology of the skin. Philadelphia: J B Lippincott, 1983:259-70.

6 Pusey CD, Venning MC, Peters DK. Immunopathology of glomerular and interstitial disease. In: Schrier RW, Gottschalk CW, eds. Diseases of the kidney. 4th ed. Boston: Little Brown, 1988:1827-83.

7 Beutner EH, Chorzelski TP, Jablonska S. Clinical significance of immunofuorescence tests of sera and skin in bullous diseases. In: Beutner EH, Chorzelski TP, Kumar V, eds. Immunopathology of the skin. 3rd ed. New York: John Wiley, 1987:177-205.

(Accepted 14 May 1991)
Department of Paediatrics, Kolding Hospital, Denmark

Ole D Wolthers, MD, research fellow

Søren Pedersen, MD, consultant paediatrician

Correspondence to: Dr O D Wolthers, Siriusvej 9, DK-8270 Højbjerg,

Denmark.

BMf 1991;303:163-5

\title{
Growth of asthmatic children during treatment with budesonide: a double blind trial
}

\author{
Ole D Wolthers, Søren Pedersen
}

\begin{abstract}
Objective-To determine whether the inhaled glucocorticosteroid budesonide has any adverse effect on short term linear growth in children with mild asthma.

Setting-Outpatient clinic in secondary referral centre.

Patients - 15 children aged 6-13 years with normal statural growth velocity during the previous year, no signs of puberty, and no use of systemic or topical steroids in the two months before the study.

Design of interventions-Double blind, randomised crossover trial with two active periods in which budesonide was given in divided daily doses of $\mathbf{2 0 0}$ $\mu \mathrm{g}$ and $800 \mu \mathrm{g}$. During run in and two washout periods placebo was given. After the second washout period the children received open treatment with 400 $\mu \mathrm{g}$ budesonide daily. All periods were of 18 days' duration.

Main outcome measure-Growth of the lower leg as measured twice a week by knemometry.

Results-Mean growth velocity of the lower leg was $0.63 \mathrm{~mm} /$ week during run in and during washout $0.64 \mathrm{~mm} /$ week. Budesonide treatment was associated with a significant dose related reduction of growth velocity: the mean reduction in growth velocity during treatment was $0 \cdot 11$ ( $95 \%$ confidence interval -0.15 to 0.37$) \mathrm{mm} /$ week with $200 \mu \mathrm{g}$ budesonide and $0.36(0.13$ to 0.59$) \mathrm{mm} /$ week with $800 \mu \mathrm{g}$ budesonide ( $<<0.05 ;$ Page's test). During treatment with $400 \mu \mathrm{g}$ budesonide a reduction of $0.17(-0.10$ to 0.45 ) $\mathrm{mm} /$ week was found.
\end{abstract}

Conclusions - Treatment with inhaled budesonide is associated with a dose related suppression of short term linear growth in children with mild asthma.

\section{Introduction}

The risk of systemic side effects of inhaled glucocorticosteroids in children with asthma has been much debated ${ }^{1-7}$ Special attention has been paid to the risk of growth suppression, ${ }^{8-18}$ but studies on this issue have been associated with methodological problems and conflicting results have been reported. ${ }^{719}$ Recently, however, knemometry has been established as a powerful tool for monitoring short term linear growth in children, measuring changes in lower leg length with an accuracy of $0 \cdot 09-0 \cdot 16 \mathrm{~mm} .{ }^{20-22} \mathrm{It}$ has been suggested that this method may be a useful physiological alternative or adjunct to the biochemical measures of systemic effects of topical steroids in children. ${ }^{23}{ }^{24}$ The aim of the present study was to investigate by means of knemometry whether the inhaled glucocorticosteroid budesonide has any adverse effect on short term linear growth in children with mild asthma.

\section{Patients and methods}

When planning the study we estimated the standard deviation of the mean growth rate of the lower leg to be $0.20 \mathrm{~mm} /$ week. $^{25}{ }^{26}$ On this assumption we calculated that 12 patients would be sufficient for a power of 0.90 to detect a $50 \%$ reduction in growth rate, which was considered a clinically relevant difference. ${ }^{27}$ A $20 \%$ rate of withdrawals was estimated, thus increasing the study population by three patients. 